J. Clin. Chem. Clin. Biochem.

Vol. 18, 1980, pp. 111-116

\title{
Ribosomal Protein Modifications in Liver Injury: Effect of Carbon Tetrachloride and Extrahepatic Cholestasis on Protein Phosphorylation
}

\author{
By A. M. Gressner
}

Department of Clinical Chemistry and Pathobiochemistry of the Medical Faculty of the RWTH, Aachen, FRG

(Received April 20/September 5, 1979)

Summary: The phosphorylation of ribosomal proteins in rat liver injured for various times by carbon tetrachloride and extrahepatic cholestasis was studied. The incorporation of $\left[{ }^{32} \mathrm{P}\right]$ phosphate into the protein moiety of the small ribosomal subunit was increased over 2 -fold 1 to $4 \mathrm{~h}$ after injection of the hepatotoxin, whereas the specific activity of the $60 \mathrm{~S}$ subunit was low and changed only insignificantly. Two-dimensional electrophoretic analysis of ribosomal proteins complemented by autoradiography revealed that $\mathrm{CCl}_{4}$ stimulated the phosphorylation of only a single protein (S6) in the $40 \mathrm{~S}$ subunit. The phosphorylation of S6 led to a measurable anodic shift and elongation of the protein on the 2-dimensional electropherograms.

In response to bile duct ligation a similar increase in phosphorylation of protein S6 was noticed.

\section{Ribosomale Proteinmodifikationen bei Leberschädigungen: \\ Einfluß von Tetrachlorkohlenstoff und extrahepatischer Cholestase auf die Proteinphosphorylierung}

Zusammenfassung: Die Phosphorylierung ribosomaler Proteine in der Rattenleber, die unterschiedlich lang durch Tetrachlorkohlenstoff und extrahepatische Cholestase geschädigt worden war, wurde untersucht. Die Inkorporation von [ $\left.{ }^{32} \mathrm{P}\right]$ phosphat in den Proteinanteil der kleinen ribosomalen Untereinheit war über 2 fach erhöht 1 bis 4 Stunden nach Gabe des Hepatotoxins, wohingegen die spezifische Aktivität der 60S Untereinheit niedrig war und sich nur unbedeutend änderte. Zwei-dimensionale Elektrophoresen ribosomaler Proteine, ergänzt durch Autoradiographie, zeigten, daß $\mathrm{CCl}_{4}$ die Phosphorylierung nur eines Proteins (S6) in der $40 \mathrm{~S}$ Subfraktion stimulierte. Die Phosphorylierung von S6 führte zu einer meßbaren anodischen Verlagerung und Elongation dieses Proteins auf den 2-dimensionalen Elektropherogrammen.

Eine Ligatur des Gallenganges fụhrte zu einem vergleichbaren Anstieg der Phosphorylierung von Protein S6.

\section{Introduction}

General subcellular reactions to toxic liver cell injury are disruption of the rough endoplasmic reticulum, disaggregation of polyribosomes into monomers, detachment of the ribosomes from the membrane and a reduction in the number of ribosomes per cell (1). These ultrastructural changes are associated with impaired synthesis of both liver and exported hepatogenic proteins. By introduction of high-resolution electrophoresis $(2,3)$, affinity labeling $(4,5)$, lactoperoxidase iodination $(6,7)$ and reductive alkylation $(4,8,9)$ of liver ribosomal proteins it became possible to extend the examination of ribosomal pathology to the molecular level (10). Studies employing these techniques revealed profound alternations of ribosomal conformation (9) and reversible chemical modifications of specific ribosomal proteins $(11,12)$ during altered liver metabolism. Structural variations of this kind and modulation of ribosomal activity are interrelated $(4,13)$.

It has been shown that the state of phosphorylation of protein $\mathbf{S 6}$ from the small ribosomal subunit of liver ribosomes ( $\mathrm{S} 6$ is the major phosphorylated site in normal eukaryote ribosomes $(11,14-16)$ ), is significantly enhanced when the liver is injured by toxic agents (17). However, the degree of phosphorylation, and the number and identity of phosphorylated ribosomal proteins in carbon tetrachloride damaged livers have not been investigated so far. In addition to this widely used model of drug-induced liver damage, we have studied the phosphorylation of protein $\$ 6$ in response. to experimental bile-duct obstruction. The latter disease 
was chosen since it resembles more closely human liver pathology and involves changes of cellular protein synthesis which are quite different from those observed in $\mathrm{CCl}_{4}$-evoked liver disease (18).

\section{Materials and Methods}

\section{Treatment of rats}

Male Sprague-Dawley rats $(220-260 \mathrm{~g}$ body weight, Zentralinstitut für Versuchstiere, Hannover, FRG) received standard rat diet and water ad libitum.

Between 8.00 and 11.00 a. m. the animals were injected subcutaneously (back skin) with $\mathrm{CCl}_{4}$ (Merck, Darmstadt, FRG), $2.5 \mathrm{ml} / \mathrm{kg}$ body weight, freshly dissolved in paraffinum liquidum (volumes, $50 \mathrm{ml}+25 \mathrm{ml}$ ). Control rats received a similar volume of paraffinum alone. 1,2 , and $4 \mathrm{~h}$ later the rats were injected intraperitoneally with $37 \mathrm{MBq} \cong 1 \mathrm{mCi}\left[{ }^{32} \mathrm{P}\right.$ ]o-phosphoric acid (carrierfree, New England Nuclear Corp., Boston, USA) and sacrificed $30 \mathrm{~min}$ thereafter.

Ligation of the common bile duct was performed under light ether anesthesia. The bile duct was dissected from surrounding structures and two silk ligatures were passed behind the common duct just distal to the junction of the hepatic ducts. Sham operated rats were treated identically but the ligation was omitted. 1, 2, and 3 days after operation the animals were decapitated, blood was collected from the neck vessels and nonhemolytic serum prepared.

\section{Isolation of liver ribosomes, ribosomal subunits and ribosomal protein}

Livers were quickly removed, chilled in ice-cold buffer $\left(0.05 \mathrm{~mol} / 1 \mathrm{Tris}-\mathrm{HCl}, \mathrm{pH} 7.6\right.$ at $20^{\circ} \mathrm{C}, 0.08 \mathrm{~mol} / 1 \mathrm{KCl}$, $0.0125 \mathrm{~mol} / 1 \mathrm{MgCl}_{2}$ ) and ribosomes (19) and ribosomal subunits (20).were prepared. Ribosomes from cholestatic livers were isolated in buffer containing $0.1 \mathrm{mmol} / 1 L$-p-bromotetramisole oxalate (Aldrich Chemical Comp., Milwaukee, USA) which acts as a stereospecific, noncompetitive inhibitor of alkaline phosphatase $(21,22)$. The concentration used inhibited the activity of the enzyme in total liver homogenate by $86 \%$. Ribosomal proteins were extracted from subunits with acetic acid $(23,24)$ and their concentrations were determined $(25)$ using bovine serum albumin as a standard. The specific radioactivity of the microsomes, of the ribosomal particles (counts/ $\mathrm{min} \cdot \mathrm{E}_{260}$ unit) and of ribosomal protein (counts/min $\cdot \mu \mathrm{g}$ protein) were measured as described (11).

\section{Two-dimensional polyacrylamide gel electrophoresis and autoradiography of ribosomal proteins}

About $540 \mu \mathrm{g}$ and $630 \mu \mathrm{g}$ of ribosomal proteins extracted from the $40 \mathrm{~S}$ and $60 \mathrm{~S}$ subunit, respectively, were separated by twodimensional electrophoresis on small polyacrylamide gel slabs (11). For autoradiography the dried gels were exposed for 14 days to Kodak Kodirex X-ray film. To determine the radioactivity comigrating with protein $S 6$ the area of protein $S 6$ was excised from the gel, sliced in $1 \mathrm{~mm}$ strips, digested (26) and counted as described (11).

Ribosomal proteins were enumerated according to the nomenclature of Sherton \& Wool (27).

For estimation of the phosphorylation state of protein $\$ 6$ in injured liver as visualized on the electropherograms, the elongation angle $\left(\mathrm{e}^{0}\right)$ and the area of phosphorylated S6 (ap) were calculated (fig. 2F). A vertical line was constructed through the center of protein S4 and the area of S6 located anodically from this line was measured with transparent mm-paper. The elongation angle is defined as the angle between the vertical line crossing the center of S4 and the line touching the most anodic part of stained protein $\mathrm{S} 6$.

\section{Determination of bilirubin concentration and enzyme activities} in serum

To verify the effectiveness of the ligation of the ductus choledochus, serum was analysed with a DuPont Automatic Clinical
Analyzer for total bilirubin concentration (28) and with an Eppendorf enzyme automate 5020 for the activities of alanine aminotransferase (EC 2.6.1.2) (29), aspartate aminotransferase (EC 2.6.1.1) (30), alkaline phossphatase (EC 3.1.3.1) (31), and leucine arylamidase (EC 3.4.1.1) (32).

\section{Results}

\section{Carbon tetrachloride induced liver injury}

The incorporation of $\left[{ }^{32} \mathrm{P}\right]$ phosphate into liver microsomes and crude ribosomal particles was stimulated 1.5and 1.8-fold above normal at one hour after administra-

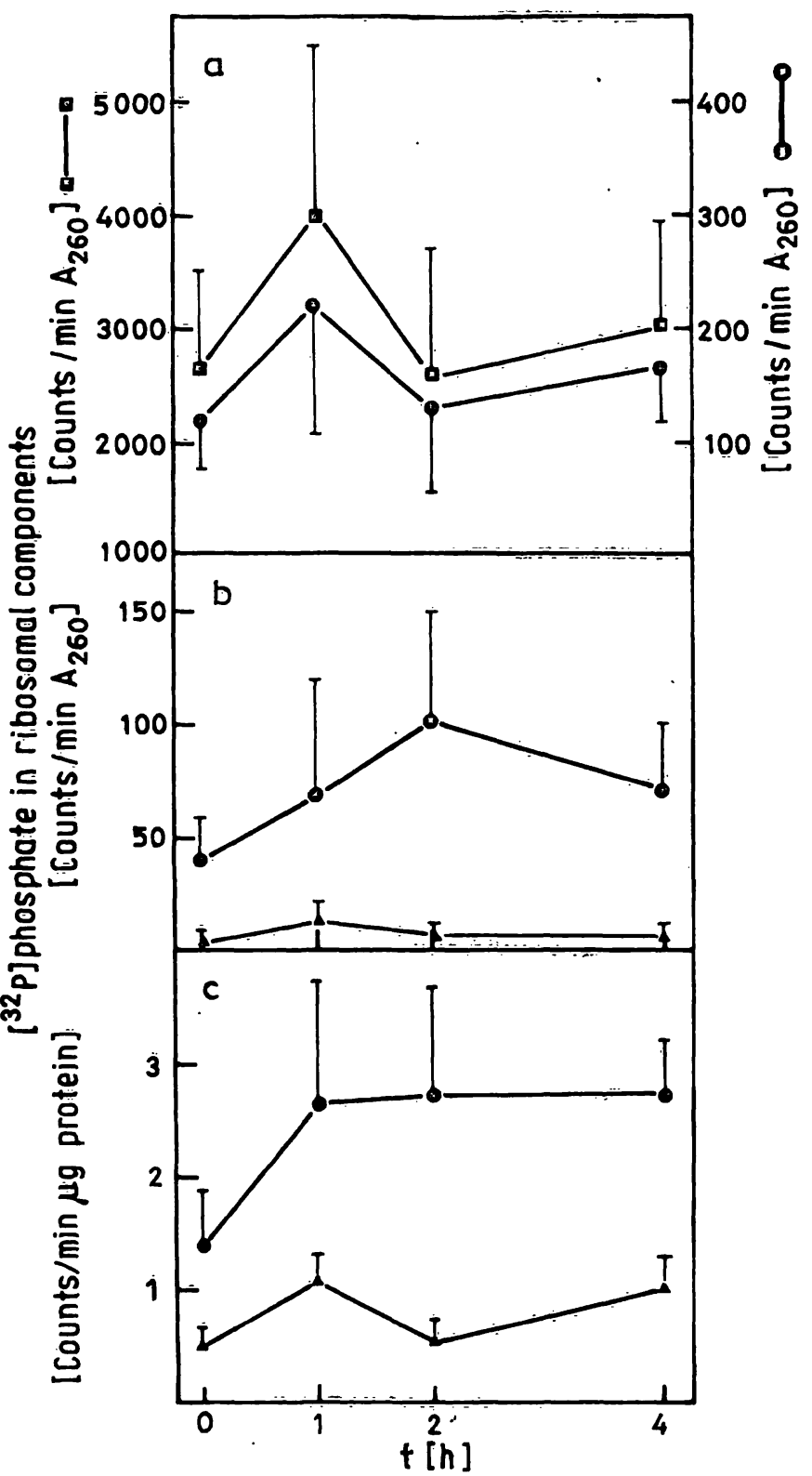

Fig. 1. The effect of carbon tetrachloride on the incorporation of [32P]phosphate into microsomes and ribosomal components of liver.

Rats were injected s. c. with $\mathrm{CCl}_{4}(2.5 \mathrm{ml} / \mathrm{kg}$ body weight) and received i. p. 1, 2 and $4 \mathrm{~h}$ later $1 \mathrm{mCi}$ [ ${ }^{32}$ P] orthophosphoric acid $30 \mathrm{~min}$ before sacrifice. The particles were isolated from liver and their specific radioactivity (counts/min $\left.\cdot \mathbf{A}_{260}\right)$ determined $(\mathrm{a}, \mathrm{C}$ microsomes, $\bullet 80$ S ribosōmes: $b, \multimap 40 \mathrm{~S}, \longleftrightarrow 60 \mathrm{~S}$ ). In $c$ the specific activity of ribosomal protein $(\bullet-40 \mathrm{~S}$, $\triangle 60 \mathrm{~S}$ ) is given. The values are the mean $\pm S$. D. of 4 separate experiments. 
tion of $\mathrm{CCl}_{4}$ but decreased to nearly control values 2 and $4 \mathrm{~h}$ later (fig. 1a). After purification and separation of ribosomal subunits in high ionic strength buffer a 2.4-fold enhancement of the incorporation of the isotope into the $40 \mathrm{~S}$ subunit ( 100 counts $/ \mathrm{min} \cdot \mathrm{E}_{260}$ ) at $2 \mathrm{~h}$ after application of the hepatotoxin was noted (fig. 1b). The specific radioactivity of the $60 \mathrm{~S}$ fraction, however, was rather low ( 7 counts $\left./ \mathrm{min} \cdot \mathbf{A}_{260}\right)$ and increased only inconsistently during the treatment. The $\left[{ }^{32} \mathrm{P}\right]$ phosphate content of ribosomal proteins extracted from the small subunit was doubled 1 to $4 \mathrm{~h}$ after injection of $\mathrm{CCl}_{4}$; the specific activity of the protein of the $60 \mathrm{~S}$ subunit reached a maximum increase at $1 \mathrm{~h}$ after onset of treatment (fig. 1c).

To study the number and location of ribosomal phosphoproteins the $40 \mathrm{~S}$ subunit proteins isolated from $\mathrm{CCl}_{4}$-injured liver were analysed by 2 -dimensional gel electrophoresis and autoradiography. Figure 2 a demonstrates the pattern of $40 \mathrm{~S}$ ribosomal proteins derived from control rat liver in which protein S6 was identified as the only radioactive ( ${ }^{32} \mathrm{P}$-containing) protein (fig. $3 \mathrm{a}$ ). Under the influence of $\mathrm{CCl}_{4}$ no additional phosphoprotein was detectable, thus the enhancement of phosphorylation of the $40 \mathrm{~S}$ subunits was strictly confined to protein S6 (fig. 3b). The increase in negative charge of this protein affected its position and shape on two-dimensional electropherograms (fig. $2 c-e$ ). It can be seen that as early as one hour after initiation of liver injury the elongation angle $\left(e^{0}\right)$ and the area (ap) of phosphorylated S6 were greatly enhanced and increased further 2 and $4 \mathrm{~h}$ later (fig. $2 \mathrm{f}-\mathrm{i}$ ). No other protein showed similar changes in its electrophoretic mobility.
By treatment of $40 \mathrm{~S}$ subunits from $\mathrm{CCl}_{4}$-injured liver with alkaline phosphatase prior to electrophoresis the anodic shift of $\mathrm{S} 6$ could be completely reversed (not shown). Figure 4 shows the distribution of radioactivity in protein $\mathrm{S} 6$ from normal and $\mathrm{CCl}_{4}$-treated liver. It is evident that liver damage for 2 and $4 \mathrm{~h}$ results in a strong increase in the number of phosphorylated amino acid residues of S6; the peak activity was located in the anodic part of the protein.

As judged from the electropherograms none of the proteins of the large ribosomal subunit was modified in $\mathrm{CCl}_{4}$-intoxicated rat liver (fig. 5).

\section{Extrahepatic cholestasis}

Occlusion of the common bile duct led to a progressive increase in the concentration of total bilirubin and leucine arylamidase activity in serum (tab. 1). The activities of alkaline phosphatase, alanine aminotransferase and aspartate aminotransferase were highest 1 day after operation but decreased sharply thereafter.

By comparison of the electropherograms of the small ribosomal subunit proteins from bile-duct ligated and sham-operated rat liver, a reduced electric mobility of protein S6 in both dimensions became visible; this clearly indicates an elevated level of phosphorylation of the protein in cholestatic liver disease (fig. 6). The elongation angle and the area of phosphorylated S6 were increased 3- and 7-fold, respectively, in response to bile duct obstruction (tab. 2).

The electropherograms did not show any other protein of the small and large ribosomal subunit (not shown) to be affected in a similar way by the operation.

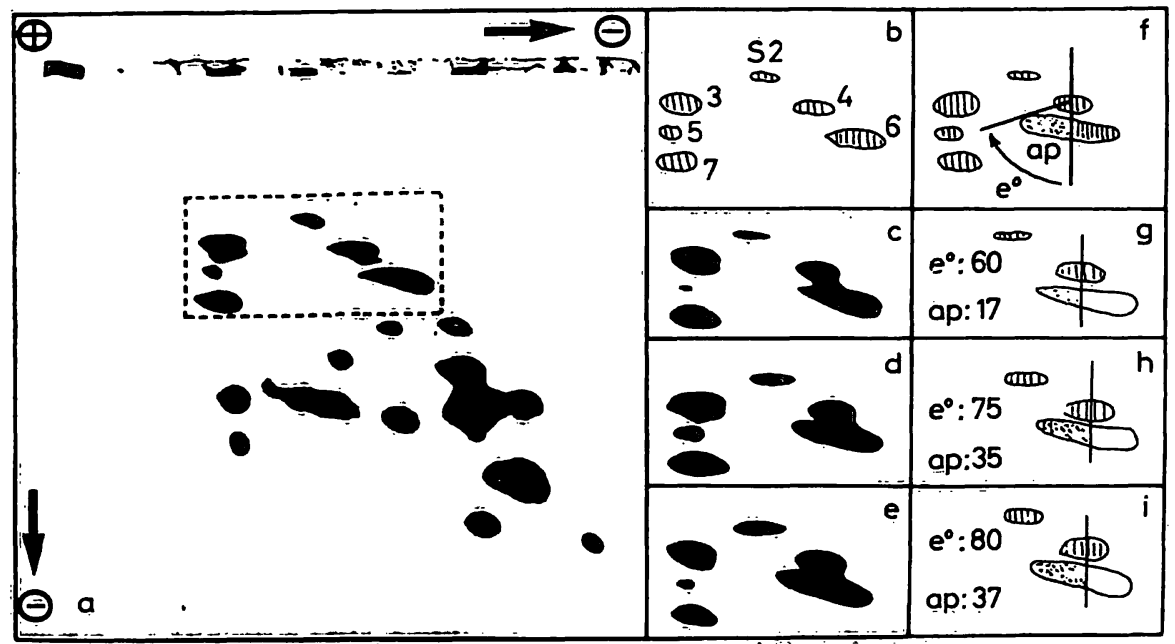

Fig. 2. Two dimensional electrophoresis of liver $40 \mathrm{~S}$ ribosomal proteins from normal and $\mathrm{CCl}_{4}$-treated rats. a represents the protein pattern of $40 . S$ subunits from control liver. The encircled region containing the proteins $S 2$ to $S 7$ is presented schematically in b. In c, d, e this region is shown from rats treated for 1,2 und $4 \mathrm{~h}$, respectively, with $\mathrm{CCl}_{4}$. In $\mathrm{f}$ the elongation angle $\left(e^{0}\right)$ and the dotted area (ap) of phosphorylated protein $S 6\left(S 6_{p}\right)$ as defined in "materials and methods" are indicated. $g, \mathrm{~h}, \mathrm{i}$ are schemes of $\mathrm{c}, \mathrm{d}, \mathrm{e}$, respectively, in which $\mathrm{e}^{0}$ and ap $\left(\mathrm{mm}^{2}\right)$ were calculated. 


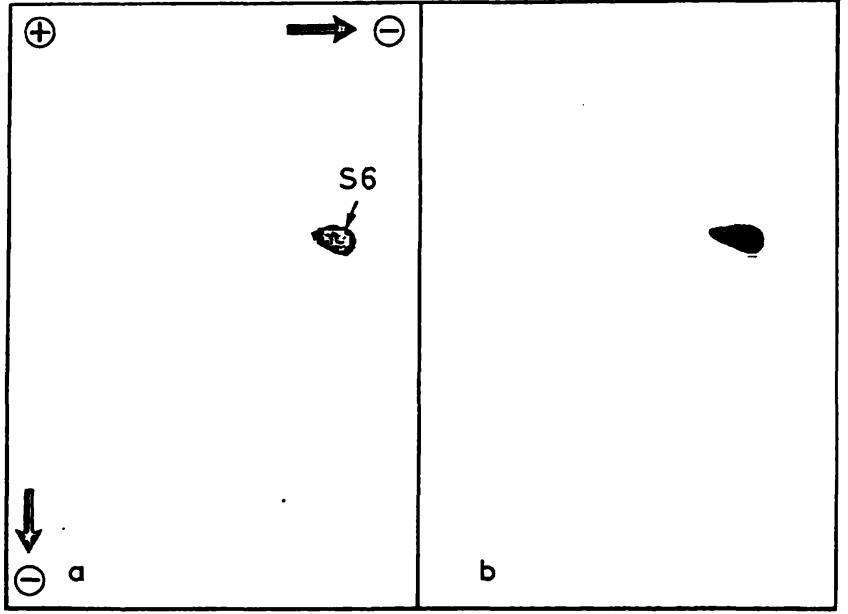

Fig. 3. Autoradiographs of $40 \mathrm{~S}$-derived ribosomal proteins from normal liver (a) and liver treated for $2 \mathrm{~h}$ with $\mathrm{CCl}_{4}$ (b). Details are described in figure 1. Protein of the $40 \mathrm{~S}$ ribosomal subunit was separated by 2 -dimensional electrophoresis and the dried gels were exposed to $\mathrm{X}$-ray film.

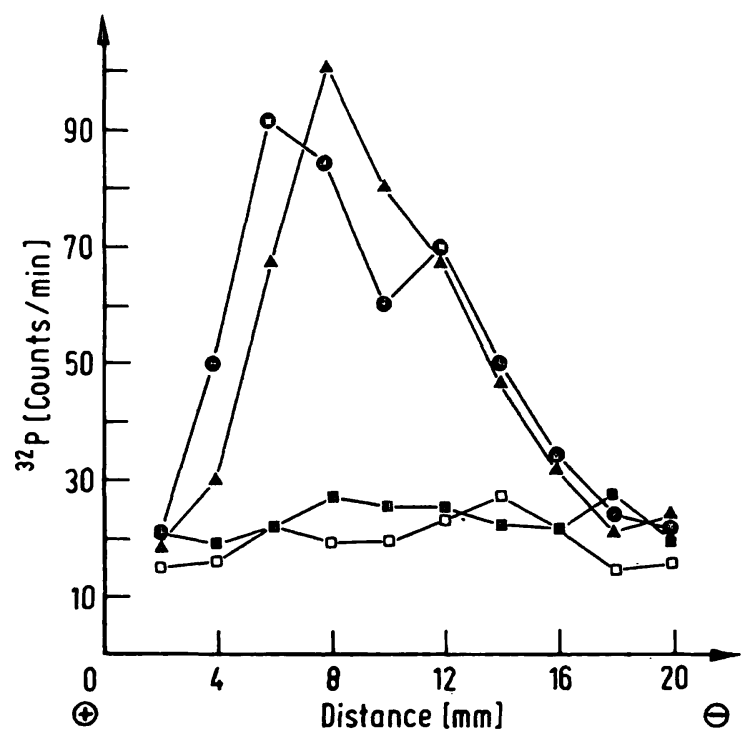

Fig. 4. The effect of $\mathrm{CCl}_{4}$-treatment on the distribution of [ $\left.{ }^{32} \mathrm{P}\right]$ activity in liver ribosomal protein $\mathrm{S} 6$. Rats were pretreated as described in figure 1 . Protein S 6 separated by 2-dimensional electrophoresis was excised from the gel, sliced from anode to cathode in $2 \mathrm{~mm}$ strips and counted for radioactivity. S 6 from control $(\square), 1 \mathrm{~h}(\square-0), 2 \mathrm{~h}(\bullet-)$ ) and $4 \mathrm{~h}(\leadsto) \mathrm{CCl}_{4}$-exposed liver is shown.

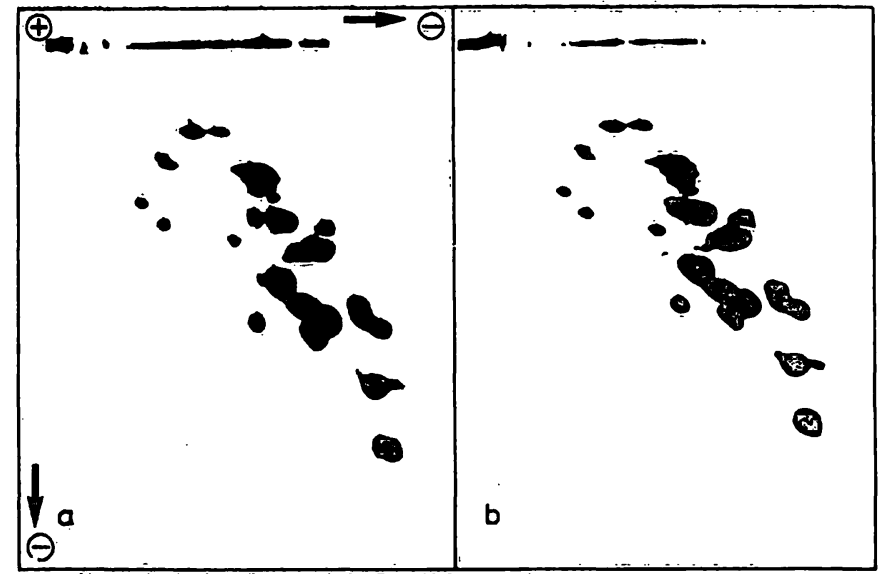

Fig. 5. Two-dimensional electropherograms of ribosomal proteins of the $60 \mathrm{~S}$ subunit isolated from the livers of control rats (a) and animals treated for $4 \mathrm{~h}$ with $\mathrm{CCl}_{4}$ (b). Details are described in figure 1.

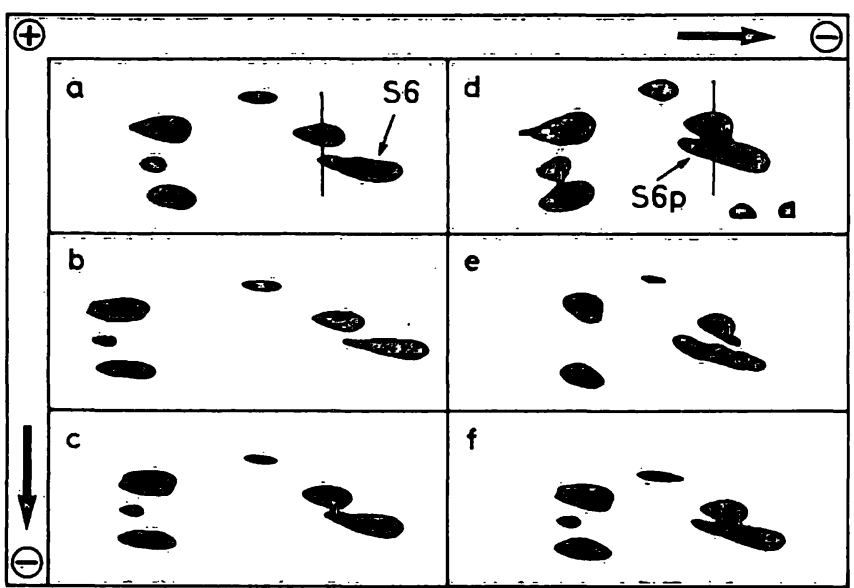

Fig. 6. Sections containing proteins $S 2$ to $S 7$ of the twodimensional electropherograms of $40 \mathrm{~S}$ ribosomal proteins from sham-operated $(a, b, c)$ and bile duct ligated $(d, e, f)$ rat liver one day $(a, d)$, two days $(b, e)$ and three days $(c, f)$ after operation. A vertical line was constructed through the center of protein $S 4$ to measure the elongation angle $\left(\mathrm{e}^{0}\right)$ and the area (ap) of $\mathrm{S} 6 \mathrm{p}$ as described in figure 2 .

Tab. 1. Concentration of total bilirubin and activities of alkaline phosphatase, leucine arylamidase, alanine aminotransferase and aspartate aminotransferase in serum of sham-operated and bile duct ligated rats 1, 2 and 3 days after operation.

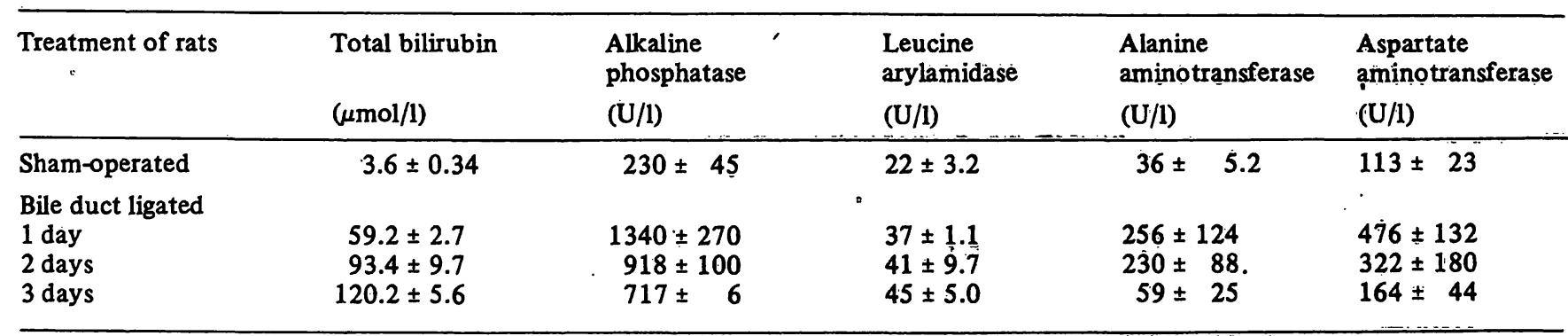

The values are the mean $\pm S$. D. of 4 to 6 separate experiments. 
Tab. 2. The effect of extrahepatic cholestasis on the phosphorylation of ribosomal protein $\mathbf{S} 6$.

1,2 and 3 days after bile duct ligation ribosomal proteins of the $40 \mathrm{~S}$ subunit were isolated and separated by two-dimensional electrophoresis. Elongation angle $\left(\mathrm{e}^{0}\right)$ and the area of phosphorylated S $6(=\$ 6 \mathrm{p})$ were calculated from the electropherograms (fig. $6 \mathrm{~d}, e, f$ ) as defined in "Materials and Methods". The values are the mean $\pm S$. D. of 3-4 experiments.

\begin{tabular}{lll}
\hline Treatments of rats & Elongation angle & $\begin{array}{l}\text { Area of } \\
\text { phosphorylated } \\
\text { S 6 } \\
\left(\mathrm{mm}^{2}\right)\end{array}$ \\
\hline $\begin{array}{l}\left(\mathrm{e}^{0}\right) \\
\text { Sham-operated }\end{array}$ & $28 \pm 5$ & $4 \pm 2$ \\
$\begin{array}{l}\text { Bile duct ligated } \\
\text { day }\end{array}$ & $73 \pm 10$ & $18 \pm 4$ \\
2 days & $75 \pm 8$ & $29 \pm 4$ \\
3 days & $77 \pm 9$ & $15 \pm 3$ \\
\hline
\end{tabular}

\section{Discussion}

As evidenced by incorporation studies of $\left[{ }^{32} \mathrm{P}\right]$ phosphate into ribosomal proteins and 2-dimensional electrophoresis complemented by autoradiography, $\mathrm{CCl}_{4}$-evoked liver damage is associated with an enhanced phosphorylation of protein $\$ 6$ of the small ribosomal subunit. The specific radioactivity of the $60 \mathrm{~S}$ particle was low and changed inconsistently during liver damage. The variation might be attributed to a contamination of the large subfraction with small amounts of phosphorylated 40 S subunits (11) rather than to a diseaseinitiated increase in the phosphorylation state of the acidic phosphoproteins discovered recently in the $60 \mathrm{~S}$ subunit $(33-38)$.

The protein modification occurs early after onset of damage, however, the interindividual variation in the rate of isotope incorporation was relatively high in the initial phase (about 50\%) in comparison to later stages of liver injury (about $25 \%$ ) (fig. 1). This is explained by a variable absorption of the drug from subcutaneous tissue. The more common way of administration of $\mathrm{CCl}_{4}$ via stomach tube was avoided since a prolonged starvation period and manipulation of the rat by intuba= tion prior to the experiment changes the phosphorylation of S6 in an unspecific and non-reproducible manner, resulting mainly from increased circulating levels of adrenalin (39).

An enhanced degree of phosphorylation of S6 was also seen in galactosamine-(40), dimethylnitrosamine-(41) and thioacetamide-(42) induced liver injury. Recovery from ethionine-generated inhibition of liver protein synthesis by treatment with adenine also leads to extensive phosphorylation of $\$ 6$ (39).

It is remarkable that obstructive jaundice, a quite different type of experimental liver disease, produces chemical modifications of $\$ 6$ similar to those in toxic liver injury.
Taken together, the results suggest an unspecific mechanism of ribosomal protein phosphorylation, which is common for the various modes of liver injury. The state of phosphorylation of $\mathrm{S} 6$ was monitored by calculation of the elongation angle and the area of phosphorylated protein S6 seen on the 2-dimensional electropherograms. The elongation angle indicates the maximum anodic shift of the protein and hence the highest phosphorylated (negatively charged) variant of S6. The phosphorylated area reflects roughly the relative amount of the modified part (S6p) of protein S6. The method might be too insensitive to detect low levels of phosphorylation of protein S6, but electrophoretic visualization and quantitation of S6p circumvents the problems inherent in studies using labeled precursors, providing special care is taken to avoid possible dephosphorylation during the preparation of the particles. Thus the use of levamisole and its analogs, which are potent, stereospecific and non-competitive inhibitors of alkaline phosphatase $(21,22)$, is a prerequisite for the isolation of $40 \mathrm{~S}$ subunits in a high phosphorylated state from cholestatic liver tissue.

The functional role of protein S6 and of its phosphorylated isoproteins are hitherto unknown. As shown in the present study elevated phosphorylation occurs in types of liver disease which have contrary effects on hepatic protein synthesis. Carbon tetrachloride causes an immediate and dose-dependent depression of amino acid polymerization (43-45) accompanied by polysome breakdown (46-48) and impaired activity of the ribosome per se (49). The latter might be a consequence of irreversible binding of the activated metabolite $\mathrm{CCl}_{3}(50)$ to ribosomal components (47). In cholestatic liver, induced either by biliary obstruction $(51,52)$ or application of $\alpha$-naphthylisothiocyanate (ANIT) to rats $(53,54)$, an increased rate of protein synthesis was found. Thus enhanced phosphorylation of protein S6 in liver disease is not causally related to the activity of the protein synthesizing machinery.

Nevertheless the phosphorylation-dephosphorylation cycle of S6 may well act as a translational control mechanism (55-59) since it might condition the binding to or release from the $40 \mathrm{~S}$ subunit of certain species of mRNA (60). Accordingly strictural changes of S6 would regulate, in a qualitative manner, the formation of the initiation complex, and thus the pattern of proteins synthesized.

The hypothesis is supported indirectly by recent results, which suggest the involvement of the ribosome in the control of protein synthesis (56). In this respect it would be of interest to learn whether the translation of individual mRNAs is differentially inhibited or amplified in injured liver cells. The question is of practical importance since it has been proposed that disease-induced changes in the profile of proteins synthesized might be more critical for the loss of liver cell integrity than an uniform shut down of general protein synthesis (61). 


\section{References}

1. Trump, B. F., Kim, K. M., Jones, R. T. \& Valigorsky, J. M. (1976), in Progress in Liver Diseases (Popper, H. \& Schaffner, F., eds.) Grune and Stratton, New York and London, $51-68$.

2. Kaltschmidt, E. \&.Wittmann, H. G. (1970), Anal. Biochem. 36, 401-412.

3. Sherton, C. C. \& Wool, I. G. (1974), J. Biol. Chem. 249, 2258-2267.

4. Bielka, H. \& Stahl, J. (1978), in Amino Acid and Protein Biosynthesis II (Annstein, H. R. V., ed.), Vol. 18 Univ. Park Press, Baltimore, 79-168.

5. Stahl, J., Dressler, K. \& Bielka, H. (1974), FEBS Lett. 47, 167-170.

6. Welfle, H. (1974), Acta Biol. Med. Germ. 33, 677-683.

7. Leader, D. P. (1975), Biochem. J. 152, 373-378.

8. Reboud, A.-M., Buisson, M., Arpin, M. \& Reboud, J.-P. (1977), Biochim. Biophys. Acta 474, 578-587.

9. Kisilevsky, R., Weiler, L. \& Treloar, M. (1978), J. Biol. Chem. 253, 7101-7108.

10. Kisilevsky, R., Treloar, M. A. \& Weiler, L. (1978), Adv. Enzyme Regul. 16, 143-164.

11. Gressner, A. M. \& Wool, I. G. (1974), J. Biol. Chem. 249, 6917-6925.

12. Gressner, A. M. \& Wool, I. G. (1976), Nature 259, 148150.

13. Wool, I. G. (1979), Ann. Rev. Biochem. 48, 719-753.

14. Gressner, A. M. \& Wool, I. G. (1974), Biochem. Biophys. Res. Commun. 60, 1482-1490.

15. Rankine, A. D. \& Leader, D. P. (1975), FEBS Lett. 52, 284-287.

16. Lastick, S., Nielsen, P. J. \& McConkey, E. H. (1977), Molec. Gen. Genet. 152, 223-230.

17. Gressner, A. M. (1979), Abstr. XIth Intern. Congr. Biochem., p. 666 .

18. Schersten, T. (1972), in Progress in Liver Diseases, Vol. IV (Popper, H. \& Schaffner, F., eds.) Grune and Stratton, New York and London, 133-150.

19. Martin, T. E. \& Wool, I. G. (1969), J. Mol. Biol. 43, 151161.

20. Stirewalt, W. S., Castles, J. J. \& Wool, I. G. (1971), Biochemistry 10, 1594-1598.

21. van Belle, H. (1972), Biochim. Biophys. Acta 289, 158168.

22. Borgers, M., De Nollin, S. \& Thone, F. (1975), Histochemistry 43, 257-267.

23. Sherton, C. C. \& Wool, I. G. (1974), Molec. Gen. Genet. $135,97-112$.

24. Hardy, S. J. S., Kurland, C. G., Voynow, P. \& Mora, G. (1969), Biochemistry 8, 2897-2905.

25. Lowry, O. H., Rosebrough, N. J., Farr, A. L. \& Randall, R. J. (1951), J. Biol. Chem. 193, 265-275.

26. Mahin, D. T. \& Lofberg, R. T. (1966), Anal. Biochem. 16, 500-509.

27. Sherton, C. C. \& Wool, I. G. (1972), J. Biol. Chem. 247, 4460-4467.

28. Jendrassik, L. \& Grof, P. (1938), Biochem. Z. 297, 81-89.

29. Bergmeyer, H. U. \& Bernt, E. (1974), in Methoden der enzymatischen Analyse (Bergmeyer, H. U., ed.) Vol. I, Verlag Chemie, Weinheim 785-791.

30. Demetriou, J. A., Drewes, P. A. \& Gin, J. B. (1974), in Clinical Chemistry (Henry, R. J., Cannon, D. C. \& Winkelman, J. W., eds.) Harper and Row, New York, 873-884.
31. Bessey, O. A., Lowry, O. H. \& Brock, M. Y. (1946), J. Biol. Chem. 164, 321-329.

32. Nagel, W., Willig, F. \& Schmidt, F. H. (1964), Klin. Wochenschr. 42, 447-449.

33. Ḧorak, I. \& Schiffmànn, D. (1977), FEBS Lett. 82, 82-84.

34. Horak, I. \& Schiffmann, D. (1977), Eur. J. Biochem. 79, 375-380.

35. Leader, D. P. \& Coia, A. A. (1977), Biochem. J. 162, 199200.

36. Leader, D. P. \& Coia, A. A. (1978), Biochem. J. 176, 569572.

37. Leader, D. P. \& Coị, A. A. (1978), Biochim. Biophys. Acta 519, 213-223.

38. Arpin, M., Madjar, J.-J. \& Reboud, J.-P. (1978), Biochim. Biophys. Acta 519, 537-541.

39. Treloar, M. A., Treloar, M. E. \& Kisilevsky, R. (1977), J. Biol. Chem. 252, 6217-6221.

40. Gressnerer, A. M. \& Greiling, H. (1977), FEBS Lett. 74, $77-81$.

41. Gressner, A. M. \& Greiling, H. (1978), Biochem. Pharmacol. 27, 2495-2498.

42. Gressner, A. M. \& Greiling, H. (1978), Exp. Mol. Pathol. 28, 39-47.

43. Smuckler, E. A., Iseri, O. A. \& Benditt, E. P. (1962), J. Exp. Med. 116, 55-71.

44. Smuckler, E. A., Iseri, O. A. \& Benditt, E. P. (1961), Biochem. Biophys. Res. Commun. 5, 270-27̄5.

45. Smuckler, E. A. (1966), Lab. Invest. 15, 157-166.

46. Farber, E., Liang, H. \& Shinozuka, H. (1971), Am. J. Pathol. 64, 601-620.

47. Castro, J. A., Diaz Gomeż, M. I., Castro, C. R., Fenos, O. M., Ferreyra, E. C. \& D'A costa, N. (1975), Res. Commun. Chem. Pathol. Pharmol. 10, 93-104.

48. Gravela, E. \& Dianzani, M. U. (1970), FEBS Lett. 9, 9396.

49. Smuckler, E. A. \& Benditt, E. P. (1965), Biochemistry 4, 671-679.

50. Recknagel, R. O. \& Glende, E. (1973), Crit. Rev. Toxicol. 2, 263-297.

51. Stäkeberg, H., Gustafson, A., Samsioe, G. \& Schersten, T. (1972), Digestion 6, 254.

52. Stakeberg, H., Lundborg, H. \& Schersten, T. (1974), Europ. J. Clin. Invest. 4, 399-403.

53. Richter, E., Grün, M. \& Kühn, H. A. (1969), Verh. Dtsch. Ges. Inn. Med. 75, 367-369.

54. Buxton, B. H., Witschi, H. \& Plàa, G. L. (1973), Toxicol. Appl. Pharmacol. 24, 60-72.

55. Lodish, H. F. (1976), Annu. Rev. Biochem. 45, 39-72.

56. Robertson, M. C. \& Bermek, E. (1977), Biochim. Biophys. Acta 476, 88-95.

57. Haselbacher, G. K., Humbel, R. E. \& Thomas, G. (1979), FEBS Lett. 100, 185-190.

58. Kruppa, J. \& Martini, O. H. W. (1978), Biochem. Biophys. Res. Commun. 85, 428-435.

59. Leader, D. P. (1979), in Protein Phosphorylation in Regulation (Cohen, P. C., ed.) Elsevier/North-Holland, Amsterdam, in presṣ.

60. Gressner, A. M. \& Van de Leur, E. (1979), FEBS Lett., submitted.

61. Farber, E. (1975), in Pathogenesis and Mechanisms of Liver Cell Necrosis (Keppler, D., ed.) MTP Press L̀td., Lancaster, 37-44.

Priv.-Doz. Dr. med. A. Gressner Abteilung Klinische Chemie und Pathobiochemie der Medizinischen Fakultät der RWTH

Goethestraße 27-29

D-5100 Aachen 